11. Cegiełka, A. Następstwa słynnego «gestu Kozakiewicza». Czy polski zawodnik rzeczywiście to planował? URL: https://wpolityce.pl/polityka/158142-nastepstwa-slynnego-gestukozakiewicza-czy-polski-zawodnik-rzeczywiscie-to-planowal.

12. Closek, J. Moskwa - miasto, $w$ którym sport przegrat $z$ polityka. URL: http://weszlo.com/2018/06/14/moskwa-miasto-ktorym-sport-przegral-polityka/.

13. Stokłosa, P. Trzej niepokorni mistrzowie. Czesść II: Władysław Kozakiewicz. https://ksiazkisportowe.blogspot.com/2012/07/trzej-niepokorni-mistrzowie-czesc-ii.html\#more.

14. HM. «Gest Kozakiewicza» wyjęty spod prawa (autorskiego)? URL: https://kultura.onet.pl/ wiadomosci/gest-kozakiewicza-wyjety-spod-prawa-autorskiego/c3w617q.

15. Hripun, R. Na Olimpiade-80 pol 'skij prygun oskvernil simvoly SSSR. Emu prishlos' bezhat'v Germaniju. URL: https://www.eurosport.ru/athletics/story_sto7486155.shtml.

16. «Gest Kozakiewicza» wyróżniony przez ESPN. - «Ręcę same się ułożyły». URL: https://onet100.vod.pl/s/sport/gest-kozakiewicza-wyrozniony-przez-espn-rece-same-sie-ulozyly/ j70emj.

17. TS/Koalicja Obywatelska. Gest Kozakiewicza. URL: https://www.nj24.pl/article/gestkozakiewicza.

18. Chojecki, P. LEGIA: gest Kozakiewicza dla Moskali. URL: http://ursatm.ru/forum/index.php?/topic/15163-legiya-zhest-kozakevicha-moskalyam/.

19. Pol'skij deputat: «Kogda Spiridonov pljunul, ja ne sderzhalsja i pokazal emu «zhest Kozakevicha». URL: https://www.sports.ru/volleyball/1023720055.html.

20. Petrov, V. Mezhdu tem. Aleksej Spiridonov: «Kakoj deputat? Kakie plevki za Krym? Jeto vse bred sumasshedshego!». URL: http://sport-weekend.com/2014-09-20-19-54-33-20323.html.

21. Ukraina zupynyla navalu Putina - Mikhnik. URL: https://antikor.com.ua/articles/34516ukrajina_zupinila_navalu_putina mihnik.

22. Pol'skij zhest dobroj voli. URL: https://uborshizzza.livejournal.com/2839045.html.

23. Passent, D. Klintona v psihushku? URL: http://ursa-tm.ru/forum/index.php?/topic/195351gostinaya-312.

Матеріал надійшов до редакції 29.10.2019 р.

УДК 334.72(100-194)-043.86

Вікторія Кухарик,

кандидат економічних наук,

асистент кафедри міжнародних економічних відносин та управління проектами, Східноєвропейський національний університет імені Лесі Українки, 43024, Україна, Волинська обл., м. Луцьк, вул. Винниченка, 28, каб. 4 kucharyk.viktoria@eenu.edu.ua

https://orcid.org/0000-0003-3389-5181

Валентин Фаримець,

студент факультету міжнародних відносин,

Східноєвропейський національний університет імені Лесі Українки

https://doi.org/10.29038/2524-2679-2020-01-21-40

\title{
СУЧАСНИЙ СТАН РОЗВИТКУ ОФШОРНОГО БІЗНЕСУ У СВІТІ
}

Особливість офшорного бізнесу - створення для підприємиів сприятливих валютнофінансового та фіскального режимів, високого рівня законодавчих гарантій

(C) Кухарик В., Фаримеияь В., 2020 
банківської та комериійної секретності, лояльного державного регулювання. Головними перевагами офиорних компаній визначено просту реєстрацію; мінімальну комісію; гнучке управління та мінімальні вимоги до звітності, мінімальну кількість директорів ц̌ акціонерів; фінансову звітність, інформаціюю про рахунки та річний прибуток або зовсім не потрібні, або залишаються мінімальними; відсутність валютного контролю; сприятливе місиеве корпоративне законодавство, сприятливі правові рамки для заохочення й стимулювання розвитку офшиорної індустрії; висока конфіденційність тошуо. Розглянуто один із глобальних трендів використання офиорної юрисдикиї світовими ТНК. Виявлено, щзо загальна сума, котра утримується в офшорних юрисдикціях, є значною. I всі иі кошти не оподатковуються повною мірою, щзо би відбувалося, якби вони були виведені в країни, де їхні материнські компанії $\epsilon$ резидентами. Але можливість створювати філії в офиорних гаванях зумовлює, поперше, економічні можливості країн, де реєструються ТНК, а по-друге, за допомогою прискореного акумулювання капіталів надає цчим ТНК не лише ринкову, економічну, але $\check{u}$ значною мірою $і$ політичну силу, а отже, вони стають значними акторами на світовій арені. Досліджено найбільші світові фінансові цеентри за індексом GCFI у 2018 р. Зроблено висновок, шуо Нью-Йорк залишається на першому місці в індексі, на 7 балів випереджаючи Лондон. Гонконг перебуває на третьому місиі, а Сингапур залишається на четвертому. Шанхай, Токіо, Торонто, Цюрих, Пекін $і$ Франкфурт залишилися в першій десятці. На основі проведеного аналізу виявлено, щзо нині, глобальний процес офиоризації економіки поглинув майже всі країни. За даними ОЕСР, щзороку світ через офшори втрачає близько 20 трлн дол. США, шо в середньому дорівнюе $10 \%$ економіки країн. Останніми роками світова спільнота дуже стурбована діяльністю офшорних компаній. Щороку розробляються нові підходи для боротьби з офиорами. Тому справедливо зазначимо, щуо світ розпочав глобальний процес деофиоризачїі світової економіки.

Ключові слова: офшор; офшорний бізнес; офшорна юрисдикція; економічна безпека країни; деофиоризація.

\section{1. ВСТУП}

Постановка проблеми. Розширення міжнародних фінансових ринків призвело до зростання мобільності капіталів, виникнення сприятливих умов для перерозподілу фінансових потоків і підприємницьких ресурсів не лише між окремими країнами, а й між групами країн. Нині міжнародна міграція капіталу відображає процеси інтернаціоналізації та глобалізації світової економіки, «офшоризація» якої останнім часом стрімко зростає й, отже, посилюється суперечливий вплив офшорів на стан світових фінансових ринків i міжнародних економічних відносин, на процеси економічного розвитку країн та відповідно на їхню економічну безпеку зокрема. Офшорний бізнес все активніше проникає в нові сфери економічної діяльності й на нові ринки. Окрім того, удосконалилися та ускладнилися методи, форми й структура ведення офшорного бізнесу.

Аналіз останніх досліджень i публікацій. Зважаючи на стрімкий розвиток офшорного бізнесу в багатьох розвинених країнах світу, дослідження вищезазначеної проблематики в останні роки є актуальним серед як зарубіжних, так і вітчизняних учених. 
Так, Ян Фіхтер, дослідивши офшорні фінансові центри в транскордонних глобальних фінансах, зробив висновок, що найбільші двосторонні відносини існують між США та Великобританією. Також важливу роль відіграють Нідерланди, Люксембург, Ірландія, Гонконг, Кайманові, Бермудські й Британські Віргінські острови [1]. Р. Хендріксе, Р. Фернандес, вивчаючи офшорні фінанси, роблять висновок, що цей офшорний світ $\epsilon$ державноствореним правовим простором в основі світової фінансової системи, а отже, це глобальний капіталізм, який охоплює світовий капітал. Учені розглядають офшорні фінанси як інтегровану систему, що здатна здійснювати політикоекономічний вплив, подібний до імперських держав минулого [2]. Г. Цукман дослідив еволюцію глобального офшорного багатства в податкових гаванях із 2001 по 2015 р. [3].

Вітчизняні дослідники також приділяють достатньо уваги проблематиці офшорного бізнесу. Так, М. І. Карлін, досліджуючи інвестиційні офшори, визначає переваги офшорних компаній [4]. 3. Луцишин зосереджує увагу на офшорних фінансових центрах у глобальному русі капіталів i сучасній офшоризації бізнесу щодо національної фіскальної безпеки [5], [6]. В. О. Мартиненко, В. П. Гордієнко у своїх працях здійснили аналіз функціонування офшорних зон, шляхи подолання наслідків їх негативного впливу на економіку України [7].

Мета статті. Мета роботи - дослідити теоретичні аспекти офшорного бізнесу, оцінити його вплив на економічну безпеку країни.

\section{2. РЕЗУЛЬТАТИ ДОСЛІДЖЕННЯ}

Нині в глобальному світі під офшорами розуміємо окремі країни, регіони, території, у яких нерезидентам законодавчо надано можливість на «пільгових» умовах зареєструвати фірму. Обов"яззковою умовою виконання діяльності офшорних фірм $є$ те, що їхніми власниками повинні бути лише нерезиденти цієї країни, а також вони повинні виконувати підприємницьку діяльність поза межами цієї країни. У цьому випадку законодавчо передбачено можливість майже повністю уникнути податків 3 операцій, приховати імена реальних продавців, покупців і бенефіціарів, незаконне походження капіталу [8].

Поняття «офшор» та «офшорний бізнес» увійшли в сучасну економічну термінологію. Офшори отримали свою назву від англійського терміна «offshore», що означає «поза берегом», «поза межами».

В економічній науці немає чітко визначеного розуміння поняття «офшор». Це зумовлено тим, що «офшор», «офшорна зона» чи «офшорний бізнес» передбачають не лише можливості відходу від «повноправного» оподаткування, але й забезпечення збереження конфіденційності, можливість ухилення від фінансового регулювання, законів i правил, що діють у юрисдикціях інших країн, у яких економічною основою $є$ реальний сектор [9].

Під офшорним бізнесом А. В. Пешко розуміє підприємницьку діяльність, що виконується в рамках міжнародної групи компаній, частина підрозділів якої 
розміщена в країнах, що надають податкові, валютні, інвестиційні й інші пільги за певних умов [10].

На нашу думку, офшорний бізнес поєднує всіх суб єктів ринку офшорних послуг. Пропонуємо до суб єеєтів офшорного бізнесу включати такі поняття, як офшорна юрисдикція (територія), офшорні зони, офшорний центр, офшорна компанія.

Розглянемо ці дефініції детальніше.

Офшорна юрисдикція (територія) - це так звана податкова гавань. У 1998 р. Організація економічного співробітництва та розвитку (ОЕСР) встановила низку факторів для ідентифікації податкових гаваней, ключовими серед яких $є$ :

1) відсутність або номінальний податок на відповідний дохід;

2) відсутність ефективного обміну інформацією;

3) відсутність прозорості;

4) жодної суттєвої діяльності [11].

Офшорними зонами називаються країни або певні їхні території, де на державному рівні для певного типу компаній, власниками яких $є$ іноземці, установлені значні привілеї в оподаткуванні, частково знижені або скасовані вимоги до бухгалтерського обліку та аудиту, частково або повністю зняті митні й торговельні межі. Офшорні зони - це недержавні фінансові центри, які здійснюють значні обсяги кредитування й фінансування у валютах інших країн. Їхніми головними характеристиками є:

- ліберальне валютно-кредитне законодавство, що захищає інтереси інвесторів, не накладаючи, таким чином, надмірних обмежень на фінансові установи (низькі податки, незначне державне втручання);

- здійснення валютних і кредитних операцій, зазвичай, в іноземній валюті для цієї країни;

- законодавче припущення про продаж валюти, коли офіційний курс обміну нижчий від ринкового й навпаки - купівля валюти, коли офіційний курс валют перевищує ринковий;

- низька або нульова ставка податку [12].

На сьогодні виокремлюють пея ять досить компактних дислокацій офшорних зон, а саме:

1. Африканську (Сейшельські острови, Ліберія, Маврикій);

2. Азіатсько-Тихоокеанську (Вануату, острови Кука, Лабуан, Науру, Самоа, Тонга й т. ін.);

3. Карибська (Ангілья, Антигуа і Барбуда, Аруба, Багамські Острови, Барбадос, Беліз, Бермудські Острови, Віргінські Острови (США), Домініка, Монтсеррат, Кайманові Острови, Гренада, Сент-Вінсент і Гренадіни, Сент-Кітс і Невіс, Сент-Люсія й ін.);

4. Свропейська (Андорра, Кіпр, Гібралтар, Гернсі, Ліхтенштейн, Мальта, Монако, острів Мен, Нормандські Острови та ін.);

5. Близький Схід (Бахрейн, Дубай, Ліван і т. ін.), [13, с. 61]. 
Загалом, у світі нараховується близько півсотні офшорних зон. За орієнтовними підрахунками, 9,8 \% усіх коштів на планеті сконцентровано саме там. Загальна сума, котра зберігається в офшорних зонах, може сягати 32 трлн дол. США - це більше за ВВП США і Японії, разом узятих [14].

Офшорна компанія - це спосіб ведення бізнесу зі значною економією на податкових видатках. Відкрити фірму в офшорній зоні може не лише власник великого бізнесу, але й звичайний фрилансер. Різні схеми податкових виплат і широка географія офшорних юрисдикцій надають великі можливості для ефективного ведення справ. Для реєстрації або переоформлення компанії в офшорі можна вибрати будь-яку частину світу. Важливо лише знати особливості офшорних зон різних типів [15].

Зазвичай, офшорні компанії реєструються в невеликих державах, на островах із невисоким рівнем розвитку власної економіки, але з досить високою політичною стабільністю (на Багамських Островах, Британських Віргінських Островах, Вануату, Сейшельських Островах, у Белізі, Панамі, Домініці, СентВінсенті й Гренадинах) [4, с. 21].

У світовій практиці найчастіше реєструють такі типи офшорних компаній:

1) фірми-«скарбнички» для накопичення грошових коштів;

2) підприємства для проведення транзитних торгових операцій;

3) фірми-«роялті», що збирають різні ліцензійні виплати за патенти, авторські гонорари та інші подібні відрахування;

4) фірми-перевізники й судноплавні компанії, що займаються морськими та авіаперевезеннями як власними, так і зафрахтованими суднами й літаками під прапором офшорної держави;

5) страхові компанії, котрі займаються перестрахуванням ризиків або страхують «дружні» компанії;

6) банки, банківські філії та кредитні установи;

7) фінансові компанії й брокерські фірми;

8) інвестиційні та трастові компанії, що управляють грошовими активами клієнтів;

9) холдингові компанії;

10) штаб-квартири компаній (наймають велику кількість співробітників);

11) інформаційні агентства та видавничі фірми [16, с. 193].

Основними причинами, відповідно до яких, офшорний бізнес $\epsilon$ привабливим вважаються такі:

1. Вартість. Найчастіше, найбільшим чинником офшорингу є здатність виробляти товари або послуги, які надаються в набагато дешевшій країні. Незалежно від того, чи це автомобільні запчастини, виготовлені в Таїланді, або IT-послуги, що надаються 3 Індії, економія коштів компанії, розміщеної в США, може бути значною.

2. Податки й тарифи. Низка рішень, що стосується офшорів, зумовлені бажанням скористатися певними податками чи звільненням від оподаткування в деяких країнах. У багатьох державах існує велика кількість податкових і 
тарифних режимів, які дають змогу компаніям створювати великі заощадження та імпортувати товари для порівняно дешевого використання.

3. Контроль. Ключовою причиною, яку компанія вибере для офшорних (на відміну від аутсорсингу), полягає в тому, що вони не хочуть відмовлятися від контролю частини своєї продукції (або внутрішніх бізнес-послуг) третій стороні. Деякі виробничі ресурси надзвичайно чутливі або залежать від часу i, якщо постачальник не доставив точно, як очікувалося, це може стати катастрофічним для компанії, яка здійснює аутсорсинг. У таких ситуаціях компанія може вибрати офшор i, в підсумку, зберігати повний контроль та відповідальність [17, с. 127-128].

Отже, основними причинами, що стимулюють розвиток офшорного бізнесу, є:

1) укрупнення транснаціональних компаній i зростання їхніх прибутків через монополізацію ринку. Практично всі ТНК користуються послугами офшорних центрів. Так, наприклад, 31 \% чистого прибутку американських ТНК припадає на офшорні зони;

2) пріоритет у розвинених країнах сфери послуг, особливо фінансових, торгівлі нерухомістю й сектору «нової економіки». Офшорні компанії зосереджують свою діяльність, насамперед, у сфері послуг;

3) формування глобальних фінансових ринків, а у зв язку 3 цим - i великих офшорних ринків;

4) зростання масштабів валютного й фондового ринків і спекулятивних операцій на них, прибуток від яких виводиться в офшори;

5) посилення соціального розшарування, яке зумовлене прискореними темпами зростання доходів найбагатших людей планети;

6) криміналізація економіки. Глобальна фінансова система все більше набуває якостей, що сприяють відмиванню грошей, у звеязку з цим затребувана конфіденційність, що надається офшорами;

7) розвиток інформаційних технологій, що є ключовим фактором, який зумовив динамічний розвиток офшорних зон в останні десятиліття. Інтернет, банківські мережі, SWIFT (міжнародна міжбанківська система передачі інформації та здійснення платежів), мобільні телефони, супутниковий зв язок дають змогу миттєво проводити різноманітні фінансові трансакції в будь-який час доби. Сучасні засоби комунікації $\epsilon$ необхідною інфраструктурою для функціонування офшорних центрів [18].

Розглянемо один із глобальних трендів використання офшорної юрисдикції світовими ТНК.

ТНК США з рейтингу «Fortune 500» утримують понад 2,6 трлн дол. США прибутку в офшорах. Про це повідомляють 293 компанії (59 \% від загальної кількості). Лише чотири з цих компаній - Apple, Pfizer, Microsoft i General Electric - становлять чверть від загальної суми. Усього 30 компаній із рейтингу «Fortune 500»- це 68 \%, або 1,76 трлн дол. США прибутку від використання офшорних юрисдикцій (рис. 1) [19]. 
РОЗДІЛ І. Міжнародні відносини. 1(7), 2020

\begin{tabular}{|c|c|c|c|c|c|}
\hline Company & $\begin{array}{l}\text { Amount Held } \\
\text { Offshore } \\
\text { ( } \$ \text { millions) }\end{array}$ & $\begin{array}{l}\text { Number of } \\
\text { Tax Haven } \\
\text { Subsidiaries }\end{array}$ & Company & $\begin{array}{l}\text { Amount Held } \\
\text { Offshore } \\
\text { ( } \$ \text { millions) }\end{array}$ & $\begin{array}{l}\text { Number of } \\
\text { Tax Haven } \\
\text { Subsidiaries }\end{array}$ \\
\hline Apple & 246,000 & 3 & PepsiCo & 44,900 & 133 \\
\hline Pfizer & 198,944 & 157 & $\begin{array}{l}\text { J.P. Morgan Chase } \\
\& \text { Co. }\end{array}$ & 38,400 & 170 \\
\hline Microsoft & 142,000 & 5 & Gilead Sciences & 37,600 & 13 \\
\hline General Electric & 82,000 & 22 & Amgen & 36,600 & 9 \\
\hline $\begin{array}{l}\text { International } \\
\text { Business Machines }\end{array}$ & 71,400 & 18 & Coca-Cola & 35,500 & 14 \\
\hline Johnson \& Johnson & 66,200 & 60 & Qualcomm & 32,500 & 4 \\
\hline Cisco Systems & 65,600 & 54 & $\begin{array}{l}\text { Goldman Sachs } \\
\text { Group }\end{array}$ & 31,240 & 905 \\
\hline Merck & 63,100 & 115 & $\begin{array}{l}\text { United } \\
\text { Technologies }\end{array}$ & 31,000 & 30 \\
\hline Google & 60,700 & 1 & AbbVie Inc & 29,000 & 40 \\
\hline Exxon Mobil & 54,000 & 38 & Eli Lilly & 28,000 & 35 \\
\hline Procter \& Gamble & 49,000 & 32 & Wal-Mart Stores & 26,600 & \\
\hline Oracle & 47,500 & 5 & $\begin{array}{l}\text { Hewlett Packard } \\
\text { Enterprise }\end{array}$ & 26,200 & 22 \\
\hline Citigroup & 47,000 & 137 & $\begin{array}{l}\text { Bristol-Myers } \\
\text { Squibb }\end{array}$ & 25,700 & 29 \\
\hline Chevron & 46,400 & 8 & $\begin{array}{l}\text { Abbott } \\
\text { Laboratories }\end{array}$ & 24,000 & 111 \\
\hline \multirow[t]{2}{*}{ Intel } & 46,400 & 14 & Danaher & 23,000 & 29 \\
\hline & & & Total: & $1,765,484$ & 2,213 \\
\hline
\end{tabular}

Рис. 1. ТНК США, які утримують найбільще грошей в офиорах [19]

Отже, як видно з рис. 1, загальна сума, що утримується в офшорних юрисдикціях, є значною. I всі ці кошти не оподатковувалися повною мірою, якби вони були виведені в країни, де їхні материнські компанії є резидентами. Але можливість створювати філії в офшорних гаванях зумовлює, по-перше, економічні можливості держав, де реєструються ТНК, а по-друге, за допомогою прискореного акумулювання капіталів надає цим ТНК не лише ринкову, економічну, але значною мірою й політичну силу, а отже, вони стають значними акторами на світової арені.

Окрім того, 40 \% усіх прямих іноземних інвестицій (ПII) (близько 15 трлн дол. США), які щороку здійснюються світовими ТНК, насправді $є$ «фантомним капіталом» для приховування їхніх податків. Такі інвестиції проходять через фіктивні компанії, щоб мінімізувати податкові зобов язання своїх власників у тій чи іншій країні світу. 
Відповідно до офіційної статистики, Люксембург, населення якого становить близько 600 тис. осіб, приймає стільки ж ПІІ, скільки США, та значно більше, ніж Китай. На кожного мешканця цієї держави припадає 6,6 млн дол. США ПІІ. Цікаво, що в декількох відомих податкових гаванях зосереджена більшість фантомних ПІІ у світі. Близько половини такого капіталу надходить на рахунки в Нідерланди та Люксембург, серед інших країн - Гонконг, Британські Віргінські Острови, Бермудські Острови, Сингапур, Кайманові Острови, Швейцарія, Ірландія й Маврикій. Ці 10 країн займають понад 85 \% усіх фантомних інвестицій [20].

Нині особливістю світових фінансових потоків $\epsilon$ те, що окремі юрисдикції або цілі зони тяжіють одна до одної та формують одну складну глобальну фінансову мережу. На рис. 2 зображено двосторонні фінансові відносини між 34 територіями.

Розмір кіл на рис. 2, демонструє обсяг транскордонних фінансових потоків, а колір - рівень офшоризації. Так, сірий колір зображує юрисдикції, яких не визнають ОФЦ, червоний - ОФЦ, що існують уже давно, а жовтий - нові та потенційні ОФЦ. Так, найбільші двосторонні відносини існують між США й Великобританією. Також важливу роль відіграють Нідерланди, Люксембург, Ірландія, Гонконг, Кайманові, Бермудські та Британські Віргінські Острови [1].

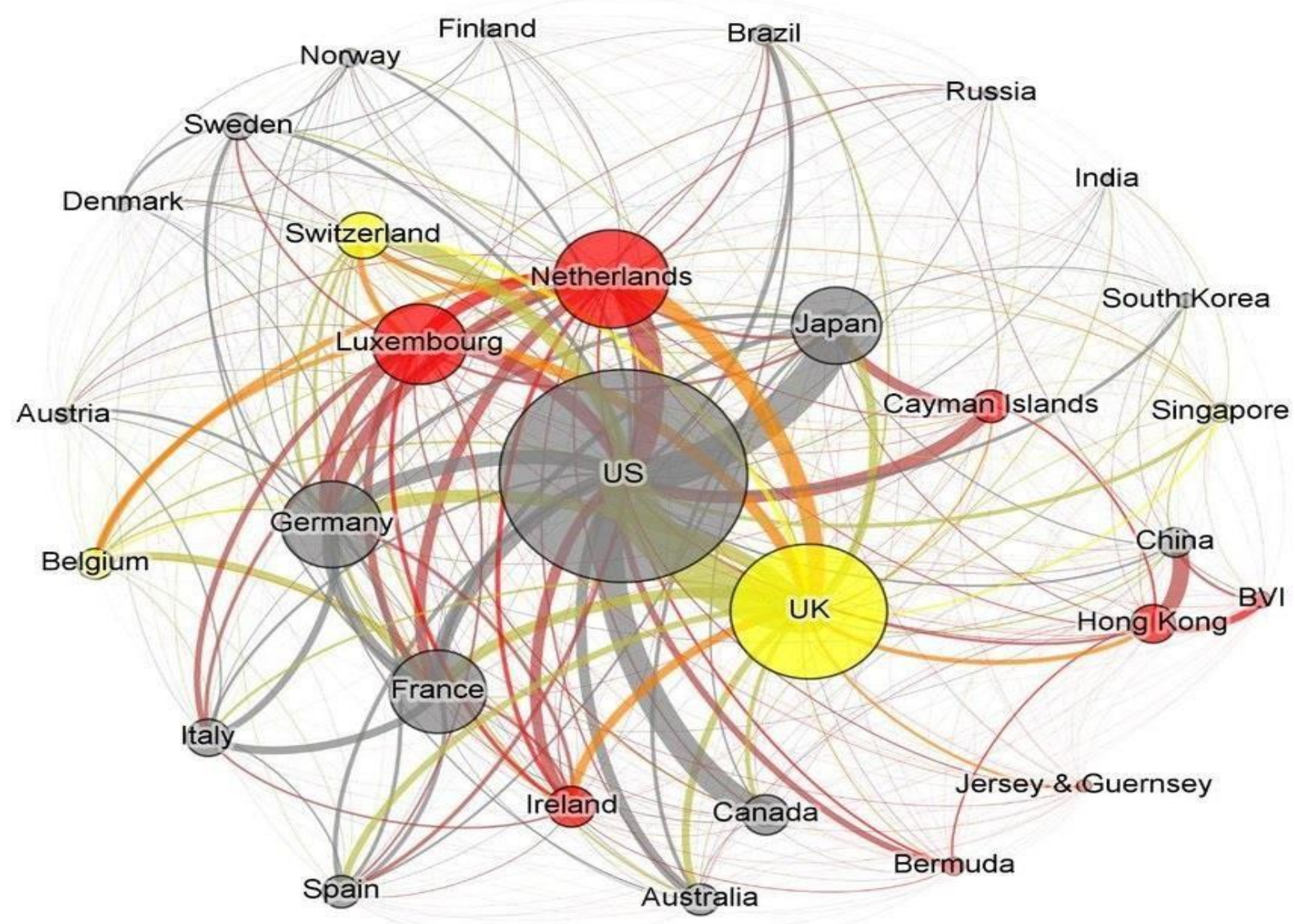

Рис. 2. Позиція найбільших офшорних фінансових центрів (ОФЦ) у транскордонних глобальних фінансах [1] 
У рейтингу ОФЦ 2019 р. OFC Meter (з англ, Offshore Financial Center Офшорний фінансовий центр) виділяє основну групу ОФЦ, які структурно охоплюють найбільшу частку акцій офшорного капіталу та потоків у всьому світі. Будучи центральною офшорною сіткою, що лежить в основі провідних світових фінансових центрів, таких як Лондон i Нью-Йорк, OFC Meter класифікує ці ОФЦ відповідно до їх використання інвестиційними фондами, багатонаціональними компаніями та банками. У ранговому порядку OFC Meter основна група складається з:

1. Кайманових Островів,

2. Люксембургу,

3. Бермудських Островів,

4. Гонконгу,

5. Нідерландів,

6. Ірландії,

7. Багамських Островів,

8. Сингапуру,

9. Бельгії,

10. Британських Віргінських Островів

11. Швейцарії [2].

Це підтверджує результати досліджень учених, політиків та організацій громадянського суспільства.

У табл. 1 показано розміри запасів капіталу, накопичених у вищезазначених офшорних центрах. Дані про кількість прямих іноземних інвестицій у та з ОФЦ, портфельні інвестиції показують різні канали й логіку, яка організовує офшорні фінансові потоки: де Кайманові Острови та Люксембург є головними напрямами для фінансових потоків інвестиційних фондів, Люксембург і Нідерланди $є$ ключовими для багатонаціональних корпорацій.

Таблиия 1

Запаси капіталу в основних офшорних центрах [21; 22]

\begin{tabular}{|c|l|c|c|c|}
\hline $\begin{array}{c}\mathbf{N o} \\
\mathbf{3} / \mathbf{I I}\end{array}$ & Офшорний центр & $\begin{array}{c}\text { Прямі іноземні } \\
\text { інвестиції } \\
\text { в ОФЦ, } \\
\text { млрд дол. }\end{array}$ & $\begin{array}{c}\text { Прямі іноземні } \\
\text { інвестиції } \\
\text { з ОФЦ, } \\
\text { млрд дол. }\end{array}$ & $\begin{array}{c}\text { Прямі портфельні } \\
\text { інвестиції ОФЦ, } \\
\text { млрд дол. }\end{array}$ \\
\hline $\mathbf{1}$ & \multicolumn{1}{|c|}{$\mathbf{3}$} & 0,942 & 0,119 & $\mathbf{5}$ \\
\hline 1 & Багамські Острови & 64,050 & 61,149 & 3,011 \\
\hline 2 & Бельгія & 0,73 & $31,045,000$ & 0,917 \\
\hline 3 & $\begin{array}{l}\text { Бермудські } \\
\text { Острови }\end{array}$ & 44,244 & 56,019 & \\
\hline 4 & $\begin{array}{l}\text { Британські } \\
\text { Віргінські Острови }\end{array}$ & 86,462 & 55,988 & 74,991 \\
\hline 5 & Гонконг & 64,535 & 94,359 & 7,064 \\
\hline 6 & Ірландія & 57,383 & 40,377 & 4,859 \\
\hline 7 & $\begin{array}{l}\text { Кайманові } \\
\text { Острови }\end{array}$ & & \\
\hline
\end{tabular}


Закінчення таблииі 1

\begin{tabular}{|c|l|c|c|c|}
\hline $\mathbf{1}$ & \multicolumn{1}{|c|}{$\mathbf{2}$} & $\mathbf{3}$ & $\mathbf{4}$ & $\mathbf{5}$ \\
\hline 8 & Люксембург & 5,615 & 1,372 & 109,944 \\
\hline 9 & Нідерланди & 239,270 & 226,429 & 68,618 \\
\hline 10 & Сингапур & 82,039 & 36,330 & 23,890 \\
\hline 11 & Швейцарія & 67,677 & 47,203 & 10,853 \\
\hline
\end{tabular}

Дані про кількість прямих іноземних інвестицій у та з ОФЦ, портфельні інвестиції показують різні канали й логіку, яка організовує офшорні фінансові потоки, де Кайманові Острови та Люксембург є головними напрямами для фінансових потоків інвестиційних фондів, Люксембург і Нідерланди $\epsilon$ ключовими для багатонаціональних корпорацій (рис. 3).

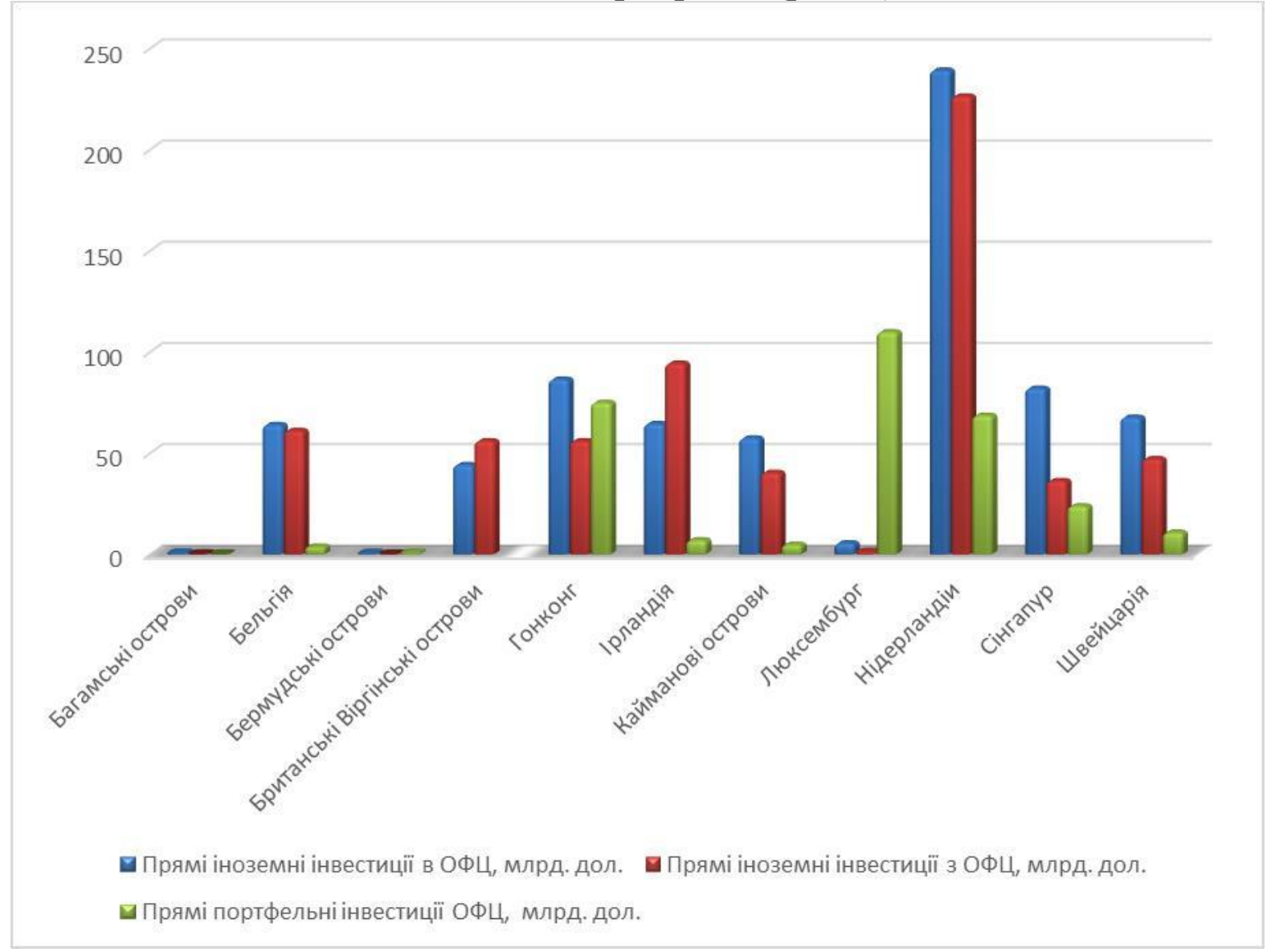

Рис. 3. Основні офморні центри та запаси капіталу в них [21; 22]

Ще один індекс, який порівнює конкурентоспроможність провідних світових фінансових центрів, $\epsilon$ The Global Financial Centres Index (Індекс глобальних фінансових центрів, GFCI). GFCI співпрацює з Інститутом розвитку Китаю. Протягом останніх 10 років GFCI публікує дві доповіді на рік, які відображають прогрес провідних світових фінансових центрів [23].

У вересні 2019 р. вийшов 26 випуск рейтингу. Найбільші світові фінансові центри за індексом GCFI у 2018 р. наведено в табл. 2. 
Таблиия 2

Топ-20 світових фінансових центрів за індексом GCFI у 2017-2018 рр. [23]

\begin{tabular}{|c|c|c|c|c|c|c|}
\hline \multirow{2}{*}{ Фінансовий центр } & \multicolumn{2}{|c|}{ GCFI 25} & \multicolumn{2}{|c|}{ GCFI 24} & \multirow{2}{*}{$\begin{array}{c}\text { Зміна } \\
\text { в рангу }\end{array}$} & \multirow{2}{*}{$\begin{array}{c}\text { Зміна } \\
\text { в рейтингу } \\
\end{array}$} \\
\hline & ранг & рейтинг & ранг & рейтинг & & \\
\hline Нью-Йорк & 1 & 794 & 1 & 788 & 0 & $\Delta 6$ \\
\hline Лондон & 2 & 787 & 2 & 786 & 0 & $\Delta 1$ \\
\hline Гонконг & 3 & 783 & 3 & 783 & 0 & 0 \\
\hline Сингапур & 4 & 772 & 4 & 769 & 0 & $\Delta 3$ \\
\hline Шанхай & 5 & 770 & 5 & 766 & 0 & $\Delta 4$ \\
\hline Токіо & 6 & 756 & 6 & 746 & 0 & $\boldsymbol{\Delta} 10$ \\
\hline Торонто & 7 & 755 & 11 & 728 & $\Delta 4$ & $\mathbf{\Delta} 27$ \\
\hline Цюрих & 8 & 739 & 9 & 732 & $\Delta 1$ & $\Delta 7$ \\
\hline Пекін & 9 & 738 & 8 & 733 & $\nabla 1$ & $\Delta 5$ \\
\hline Франкфурт & 10 & 737 & 10 & 730 & 0 & $\Delta 7$ \\
\hline Сідней & 11 & 736 & 7 & 734 & $\nabla 4$ & $\Delta 2$ \\
\hline Дубаї & 12 & 733 & 15 & 722 & $\Delta 3$ & $\Delta 11$ \\
\hline Бостон & 13 & 732 & 13 & 725 & 0 & $\Delta 7$ \\
\hline Шеньчжень & 14 & 730 & 12 & 726 & $\nabla 2$ & $\Delta 4$ \\
\hline Мельбурн & 15 & 729 & 20 & 699 & $\Delta 5$ & $\Delta 30$ \\
\hline Сан-Франциско & 16 & 727 & 14 & 724 & $\nabla 2$ & $\Delta 3$ \\
\hline Лос-Анджелес & 17 & 724 & 16 & 721 & $\nabla 1$ & $\Delta 3$ \\
\hline Монреаль & 18 & 722 & 24 & 690 & $\Delta 6$ & $\Delta 32$ \\
\hline Ванкувер & 19 & 721 & 18 & 709 & $\nabla 1$ & $\mathbf{\Delta} 12$ \\
\hline Чикаго & 20 & 717 & 17 & 717 & $\nabla 3$ & 0 \\
\hline
\end{tabular}

Аналіз вищенаведених даних свідчить про те, що Нью-Йорк залишається на першому місці в індексі, на 7 балів випереджаючи Лондон. Гонконг лише на чотири бали поступається Лондону та перебуває на третьому місці, а Сингапур залишається на четвертому місці. Шанхай залишається попереду Токіо на п“ятому місці в індексі, хоча Токіо піднявся на 10 балів у рейтингах, Торонто на 27 балів (7-ме місце). Цюрих, Пекін і Франкфурт залишилися в першій десятці.

На рис. 4 продемонстровано еволюцію глобального офшорного багатства 3 2001 р. Автори [6, с. 81] оцінили цей показник із використанням тих самих методів і джерел даних, як у Цукмана (Zucman, 2013), але, спираючись на останні доступні міжнародні інвестиційні позиції країн, вважаємо, що запас офшорного багатства залишився в межах близько 10 \% від світового ВВП, без особливої тенденції.

Відповідно до звіту Boston Consulting Group, у 2018 р. глобальне фінансове багатство зросло лише на 1,6 \% до 205,9 трлн дол. США, що значно нижче за $7,5 \%$, зафіксованих у попередньому році, і значно нижче від загального темпу зростання на 6,2\% із 2013 по 2017 р. (рис. 5). 


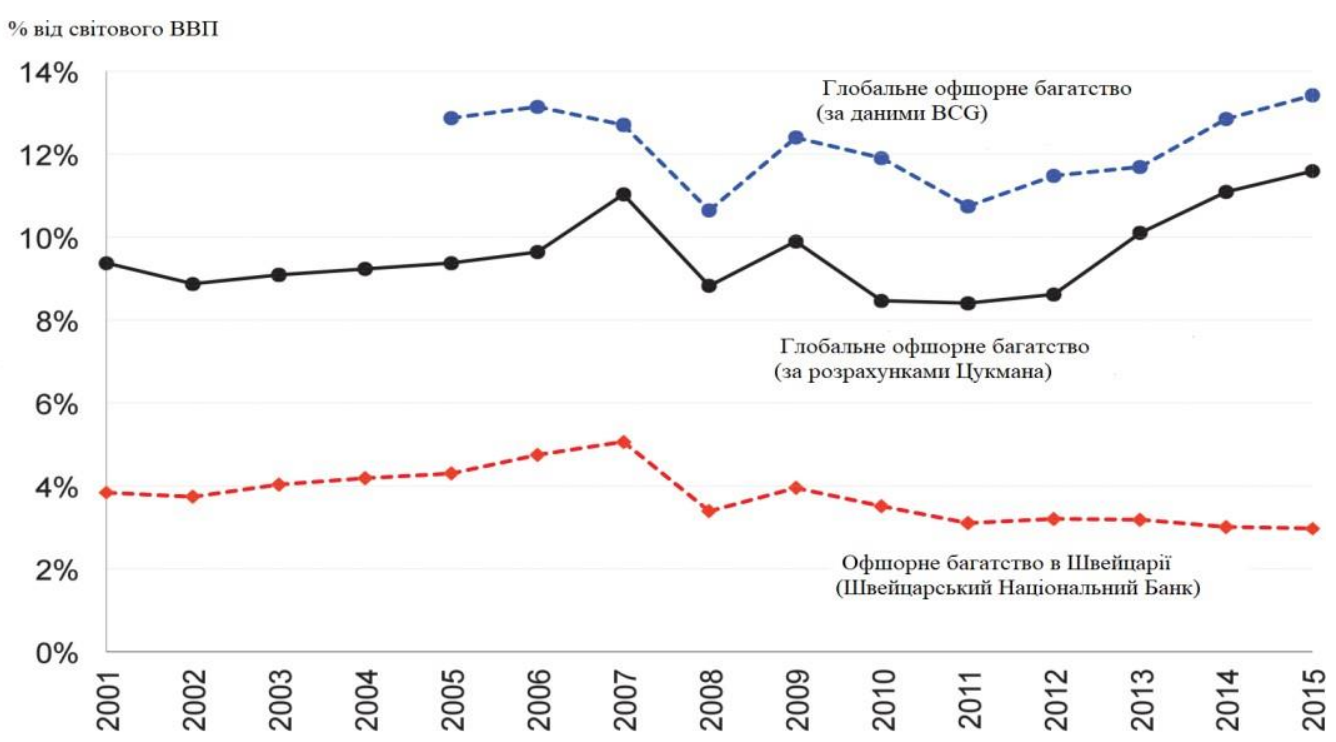

Рис. 4. Глобальний обсяг багатства в податкових гаванях [3]

Примітки. Нижня вісь відображає глобальний обсяг багатств, щуо належать домогосподарствам у всіх світових податкових оазисах наприкіниі кожного року як частка світового ВВП. Нижній рядок показує офшорні багатства, щуо зберігаються у швейцарських банках, очінені із щомісячної банківської статистики Швейцарського національного банку. Середня крива показує оцінку, отриману завдяки застосуванню методологіі Цукмана (Zuстаn, 2013) та оновленню результатів до 2015 р. У верхньому рядку подана оцінка Boston Consulting Group, яка щзорічно публікується у звіті ВCG.

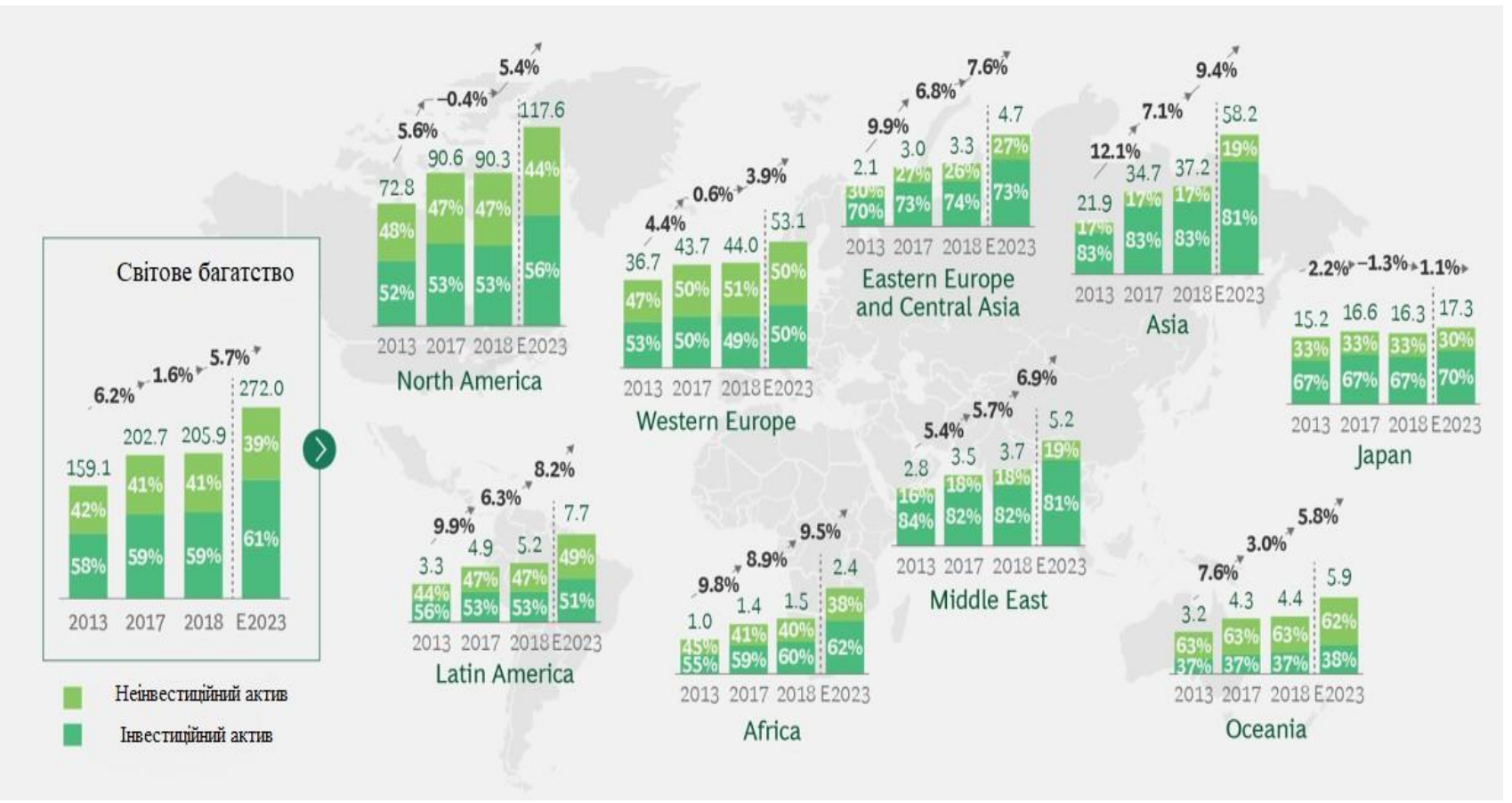

Рис. 5. Світове багатство за регіонами світу [24]

Примітка. Неінвестиційний актив - страхування життя та пенсї, власний акиіонерний капітал й інший власний капітал.

Інвестиційний актив - облігації, інвестииійні фонди, валюта та депозити тощо. 
Огляд розміру ринку у 2018 р. засвідчив різке зменшення зростання багатства в більшості зрілих ринків. У Північній Америці неінвестиційні активи знизилися на 0,3 \% за рік. Японія також зафіксувала спад на $-1,3 \%$, незважаючи на високу концентрацію депозитних портфелів. Багатство Західної Європи зросло на 0,6 \% завдяки потужним темпам зростання в таких місцях, як Німеччина, Франція та північні країни, що допомогло компенсувати зменшення темпів зростання в Італії, Іспанії й Португалії.

На «ринках, що швидко розвиваються», також спостерігаються неоднозначні результати. За винятком Японії, Азія зафіксувала зростання активів на рекордні 12,1 \% у 2017 p. і 7,1 \% у 2018 р. Падіння темпів зростання полягає в невдачах Китаю (торговельна війна зі США), на багатство якого припадає $57 \%$ усіх активів регіону.

У Східній Свропі фінансове багатство зросло на 6,8 \% у 2018 р., позитивне зростання фондового ринку відбулося завдяки накопиченому багатству в Польщі, Румунії й Чехії [24].

Падіння темпів зростання на фондовому ринку у 2018 р. посилило невизначеність щодо стану світової економіки та, зокрема, офшорного бізнесу. Задля вирішення цього питання, а також оцінки прогнозу щодо формування багатства протягом наступних п“еяти років Boston Consulting Group розробила детальні прогнози, використовуючи різні макроекономічні та ринкові показники. Згідно з базовим сценарієм, Boston Consulting Group прогнозує, що з 2018 по 2023 р. світове багатство зросте в усьому світі на 5,7\%. Північна Америка повинна продовжувати залишатись орієнтиром для створення багатства, ураховуючи вірогідність того, що ринки капіталу в Канаді й США продовжуватимуть позитивне (навіть якщо повільніше) зростання. Прогнозується, що багатство в Північній Америці зросте на 5,4 \%, досягнувши 118 трлн дол. США до 2023 р., приріст у Західній Європі коливатиметься на позначці 3,9\%, а багатство в регіоні до 2023 р. може досягти 53,1 трлн дол. США, у Японії також прогнозується збільшення багатства на $1,1 \%$ до 17,3 трлн дол. США. Історією великого зростання стане Азія. Базовий сценарій Boston Consulting Group передбачає, що багатство тут збільшиться на 9,4\%, досягнувши 58,2 трлн дол. США. Протягом наступних п“яти років у цьому регіоні прогнозується найвищий темп регіонального зростання за цей період. В інших регіонах також спостерігатиметься зростання, хоча значно нижчого рівня. За прогнозами, багатство в Латинській Америці підвищиться на $8,2 \%$ до 7,7 трлн дол. США. Загальний ріст Африки та Близького Сходу, імовірно, зросте на 7,7 \% (до 7,6 трлн дол. США). За той самий період у Східній Європі й Центральній Азії простежуватимемо колективне зростання на 7,6 \% (до 4,7 трлн дол. США), а в Океанії - на 5,8 \% (до 5,9 трлн дол. США [24].

Отже, останніми роками популярність офшорного бізнесу зменшується. Оскільки, за прогнозами, приріст витрат на офшоринг у 2018 та 2020 рр. буде значно нижчим, ніж у 2014 й 2016 рр., у більшості, випадків приблизно в тричотири рази. Цей спад відбувається в умовах скорочення загального багатства доходу у світовому масштабі з 2017 по 2018 р. 
Нині, глобальний процес офшоризації економіки поглинув майже всі країни. За даними ОЕСР, щороку світ через офшори втрачає близько 20 трлн дол. США, що в середньому дорівнює $10 \%$ економіки країн.

Останніми часом Світове Співтовариство дуже стурбоване діяльністю офшорного бізнесу. Щороку розробляються нові підходи для боротьби 3 офшорами. Тому справедливо зазначимо, що світ розпочав глобальний процес деофшоризації світової економіки.

До ефективних механізмів деофшоризації потрібно віднести заходи, які проводить ОЕСР. У звіті BEPS «Про розмивання податкової бази та виводу прибутку з оподаткування» запропонована «дорожня карта», яка дає змогу країнам отримувати належний їм прибуток від оподаткування, сприяти більшій транспарентності та покращенню обміну інформацією, неспроможності штучного переводу прибутку в низькоподаткові юрисдикції, більшій передбачуваності й упевненості бізнесу [25].

BEPS складається 315 пунктів, план покликаний поставити заслін на шляху «подвійного неоподаткування», за яким ідуть багато транснаціональних компаній. Із того часу світ почав розробляти нові правила для роботи 3 офшорами.

У 2017 р. Рада СС опублікувала перелік із понад 40 країн, оподаткування в яких не відповідає принципам прозорості та справедливості. Із них 13 названо офшорами, де осідав прибуток компаній, що не мали реальної діяльності. Погрожуючи внесенням до «чорного списку», СС змусив більшість країн провести реформи до кінця 2018 р. А вже з 2019 р. у багатьох державах почали працювати закони, що зобовеязують компанії вести реальну діяльність.

Хоча сам план BEPS ще повністю не імплементований, проте він уже впливає на плани великих міжнародних компаній, які стоять перед необхідністю реструктуризації [26].

Аналізуючи статистичні дані ОЕСР, глобальна деофшоризація набирає обертів. Зеяявляться різні методи боротьби 3 офшорами, одним із яких $\epsilon$ контроль над іноземними компаніями, правила СFC (з англ. - Controlled foreign corporation rules). У 2015 р. ОЕСР та лідери країн Великої двадцятки (G20) висвітлили фінальний звіт щодо Заходу № 3 плану BEPS «Розробка ефективних правил CFC». Цей звіт розкриває основні поняття й напрями дії в межах розробленої концепції.

На сьогодні провідною міжнародною організацією, яка бореться 3 відмиванням грошей, $\epsilon$ Група 3 розробки фінансових заходів боротьби 3 відмиванням грошей - ФАТФ (з англ. FATF - Financial Action Task Force) впливовий міжурядовий орган, створений у 1989 р. на саміті G-7 у Парижі. Завдання ФАТФ - установлення стандартів та сприяння ефективному виконанню правових, регулятивних й оперативних заходів щодо боротьби 3 відмиванням грошей, фінансуванням тероризму та іншими загрозами цілісності міжнародної фінансової системи. FATF напрацював низку Рекомендацій, які визнані міжнародним стандартом у боротьбі 3 відмиванням грошей, фінансуванням тероризму й розповсюдженням зброї масового знищення. 
Рекомендації становлять основу для координованого реагування на загрози цілісності фінансової системи. Уперше рекомендації видано в 1990 р., згодом їх переглянуто в 1996, 2001, 2003 pp., а востаннє у 2012 р., щоб вони були актуальними та загальноприйнятими [27].

18 жовтня 2019 р. у рамках постійного огляду відповідності стандартам FATF видокремив список юрисдикцій, у яких є стратегічні недоліки щодо протидії відмиванню коштів, щодо котрих вони розробили план дій (табл. 3 ).

Табличя 3

\section{Список юрисдикцій FATF, що мають високі ризики [28]}

\begin{tabular}{|c|c|}
\hline $\begin{array}{c}\text { Юрисдикція зі стратегічними } \\
\text { недоліками }\end{array}$ & $\begin{array}{c}\text { Юрисдикція, яка більше не підлягас } \\
\text { моніторингу }\end{array}$ \\
\hline Багамські Острови & Ефіопія \\
\hline Ботсвана & Шри-Ланка \\
\hline Камбоджа & Туніс \\
\hline Гана & \\
\hline Ісландія & \\
\hline Монголія & \\
\hline Пакистан & \\
\hline Панама & \\
\hline Сирія & \\
\hline Тринідад і Тобаго & \\
\hline Смен & \\
\hline Зімбабве & \\
\hline
\end{tabular}

Досліджуючи досвід країн світу в процесах деофшоризації економіки, потрібно згадати про концепцію CFC (3 англ. controlled foreign company контроль над іноземними компаніями), спрямовану саме на запобігання ухилянню від сплати податків за допомогою офшорних компаній. Суть концепції - прибуток зарубіжної компанії, яка контролюється резидентами цієї держави, для цілей оподаткування зараховується в прибуток резидента. Тому пряме використання офшорних компаній для акумулювання зарубіжних прибутків не дає власникам цих компаній законної можливості позбутися оподаткування за місцем проживання [29].

Україна теж хоче бути «у тренді» щодо глобальної деофшоризації, доказом чого є зареєстрований у Верховній Раді України у 2016 р. документ «Про внесення змін до Податкового кодексу України щодо запобігання розмиванню бази оподаткування та перенесенню прибутку в офшорні зони», що передбачає впровадження правил СFC [30].

Україна долучилися до Плану BEPS та взяла на себе зобов "язання імплементувати так званий Мінімальний стандарт Плану дій BEPS -

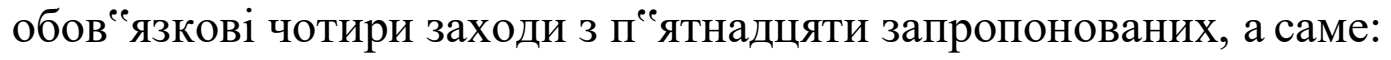

- пеятий захід, що спрямований на боротьбу 3 податковими зловживаннями, пов “еязаними з використанням спеціальних шкідливих режимів оподаткування (countering harmful tax practices); 
- шостий захід, спрямований на попередження зловживань при застосуванні конвенцій про уникнення подвійного оподаткування (preventing tax treaty abuse);

- тринадцятий захід, направлений на вдосконалення вимог чинних національних правових норм до документації з трансфертного ціноутворення (transfer pricing documentation and country-by-country reporting);

- чотирнадцятий захід, мета якого - підвищення ефективності механізмів вирішення спорів між країнами при застосуванні договорів про уникнення подвійного оподаткування (cross-border tax dispute resolution) [31].

\section{3. ВИСНОВКИ ТА ПЕРСПЕКТИВИ ПОДАЛЬШИХ ДОСЛІДЖЕНЬ}

Отже, особливістю офшорного бізнесу $є$ створення для підприємців сприятливого валютно-фінансового та фіскального режимів, високого рівня законодавчих гарантії банківської й комерційної секретності, лояльного державного регулювання. Головними перевагами офшорних компаній визначено просту реєстрацію; мінімальну комісію; гнучке управління та мінімальні вимоги до звітності, мінімальну кількість директорів й акціонерів; фінансова звітність, інформація про рахунки та річний прибуток або зовсім не потрібна, або залишається мінімальною; відсутність валютного контролю; сприятливе місцеве корпоративне законодавство, сприятливі правові рамки для заохочення та стимулювання розвитку офшорної індустрії; високу конфіденційність тощо. Деофшоризація економік країн є перешкодою розвитку офшорного бізнесу. Світовим товариством застосовується низка інструментів, спрямованих на перешкоджання застосуванню офшорних практик. Україна теж долучилася до процесу деофшоризації, зокрема до Плану BEPS, і взяла на себе зобове язання імплементувати Мінімальний стандарт Плану дій, що включає боротьбу 3 податковими зловживаннями; попередження зловживань при застосуванні конвенцій про уникнення подвійного оподаткування; удосконалення вимог чинних національних правових норм до документації 3 трансфертного ціноутворення; підвищення ефективності механізмів вирішення спорів між країнами при застосуванні договорів про уникнення подвійного оподаткування.

Перспективним у подальших дослідженнях $€$ оцінка впливу офшорного бізнесу на економічну безпеку країн, визначення позитивних i негативних наслідків.

\section{СПИСОК ВИКОРИСТАНИХ ДЖЕРЕЛ}

1. Fichtner, Jan. The Offshore-Intensity Ratio. URL: https://www.researchgate.net/publication/ 281460648_The_Offshore-Intensity_Ratio.

2. Hendrikse, Reijer, Fernandez, Rodrigo. Offshore Finance. How Capital Rules the World. URL: https://www.researchgate.net/publication/330713868_Offshore_Finance_How_Capital_Rules _the_World.

3. Alstadswter, A., Johannesen, N., Zucman, G. (2018). Who owns the wealth in tax havens? Macro evidence and implications for global inequality. Journal of Public Economics, 162 (2018), P. 93. URL: https://www.longfinance.net/media/documents/GFCI_25_Report.pdf. 
4. Карлін, М. І., Івашко, О. А. (2017). Інвестиційні офшори: навч. посіб. Луцьк: ВежаДрук, 292 с. URL: http://esnuir.eenu.edu.ua/bitstream/123456789/12272/1/ inv_ofshory.pdf.

5. Луцишин, 3., Мехтієв, Е. (2017). Офшорні фінансові центри у глобальному русі капіталів. Міжнародна економічна політика, № 2, С. 62-94. URL: http://ir.kneu.edu.ua/handle/ 2010/23852.

6. Луцишин, 3., Фролова, Т., Южаніна, Н., Мазур, М., Перебийніс, Д. (2019). Сучасна офшоризація бізнесу у конструкті національної фіскальної безпеки. Міжнародна економічна політика, Вип. 1(30), С. 70-112. URL: http://iepjournal.com/journals/30/2019_4_Lutsyshyn_\% 20Frolova_Yuzhanina_Mazur_Perebyinis.pdf.

7. Мартиненко, В. О., Гордієнко, В.П.(2018). Аналіз функціонування офшорних зон та шляхи подолання наслідків їх негативного впливу на економіку України. Економіка та суспільство, № 10. URL: http://www.economyand society.in.ua/journal/15_ukr/25.pdf.

8. Мосакова, Е. А. Оффиорный бизнес как фактор наџиональной безопасности в современном глобальном мире. URL: https://cyberleninka.ru/article/n/offshornyy-biznes-kakfaktor-natsionalnoy-bezopasnosti-v-sovremennom-globalnom-mire.

9. Черленяк, I. І., Дюгованець, О. М. (2014). Міжнародний офшорний бізнес та глобальна фінансова система. Проблеми економіки, № 2, C. 24-29. URL: http://nbuv.gov.ua/UJRN/ Pekon_2014_2_3. c. 26/

10. Пешко, А. В. (2016). Офшорний бізнес як складова світової економіки. Економіка та підприємництво, № 3, С. 233-236.

11. Countering offshore tax evasion. URL: https://www.oecd.org/ctp/exchange-of-taxinformation/42469606.pdf

12. Волкова, Ю. А. (2010). Розвиток офшорних центрів у системі міжнародного бізнесу. Формування ринкових відносин в Україні, № 1, С. 43-48.

13. Хейфец, Б. А. (2010). Офшорные юрисдикции в глобальной и национальной экономике. Москва: Економіка, 335 с.

14. Офиор - что это такое простым языком? Разбираемся в причинах скандала. URL: https://sputnik-georgia.ru/amp/spravka/20160406/231003155/Ofshor-chto-jeto-takoeprostymjazykom-Razbiraemsja-v-prichinah-skandala.html.

15. Офшорні зони: види та особливості. Газета «Вікна». URL: http://vikna.if.ua/ cikavo/68688/view.

16. Міжнародне оподаткування: навч. посіб. для студентів екон. спец. / В. І. Грушко, Ю. О. Махортов, Н. А. Телічко, В. М. Бородачова; Держ. закл. «Луган. нац. ун-т ім. Тараса Шевченка». Луганськ: Вид-во ДЗ «ЛНУ імені Тараса Шевченка», 2012. 382 с. URL: http://dspace.luguniv.edu.ua/jspui/bitstream/123456789/715/1/Telichko\%20mizn.pdf.

17. Агапова, А. І., Лободзинська, Т. П. (2018). Наслідки діяльності офшорних компаній та шляхи їх подолання. Сучасні проблеми економіки і підприємництвво, Вип. 22. С. 126-134.

18. Ярошевич, В., Сарган, А. (2013). Оффшорный сегмент мировой экономики: эволюция и тенденции развития. Банкаўскі веснік. Сакавік, С. 33-39.

19. Offshore Shell Games (2017). The Use of Offshore Tax Havens by Fortune 500 Companies. URL: https://itep.org/wp-content/uploads/offshoreshellgames2017.pdf.

20. Hidden Corners of the Global Economy. URL: https://www.imf.org/external/pubs/ $\mathrm{ft} /$ fandd/2019/09/pdf/fd0919.pdf.

21. Foreign direct investment, net inflows (BoP, current US\$). URL: https://data.worldbank. org/indicator/BX.KLT.DINV.CD.WD.

22. Paying Taxes (2018). URL: https://www.pwc.com/gx/en/paying-taxes/pdf/pwc_paying_ taxes_2018_full_report.pdf.

23. The Global Financial Centres Index 22 March (2019). URL: https://www.longfinance. net/media/documents/GFCI_25_Report.pdf. 
24. Global Wealth (2019): Reigniting Radical Growth. URL: https://www.bcg.com/ publications/2019/global-wealth-reigniting-radical-growth.aspx.

25. Підгурська, О. (2016). Тенденції міжнародної та національної антиофшорної політики. Формування ринкової економіки в Украӥні: зб. наук. праць/Львів. нац. ун-т ім. І. Франка; [редкол.: С. М. Панчишин та ін.]. Львів, Вип. 35, ч. 2, С. $94-99$.

26. Світ прощається з офиорами: Україна на черзі. URL: https://www.epravda.com.ua/ projects/offshore/2019/10/21/652665/

27. FATF. What do we do. URL: https://www.fatf-gafi.org/about/whatwedo/\#d.en.3146.

28. High-risk and other monitored jurisdictions. URL: https://www.fatf-gafi.org/publications/high-risk-and-other-monitored-jurisdictions/documents/fatf-compliance-october-2019.html.

29. Токменко, В. В. (2014). Сучасний стан та тенденції глобального регулювання офшорного бізнесу. Науковий вісник Херсонського державного університету. Серія: Економічні науки. Херсон, Вип. 8, ч. 6, С. 35-38. URL: http://www.ej.kherson.ua/journal/ economic_08/275.pdf.

30. Шокрута, В. Глобальна деофиоризачія, передумови ї̈ виникнення. URL: http://yurgazeta.com/publications/practice/inshe/globalna-deofshorizaciya-ta-yiyi-vpliv-na-zed.html.

31. Україна і план BEPS: чому офшори відходять у минуле. URL: https://www.epravda. com.ua/projects/offshore/2019/10/29/652879.

\section{CURRENT STATUS OF OFFSHORE BUSINESS DEVELOPMENT IN THE WORLD}

The creation of favorable monetary, financial and fiscal regimes for entrepreneurs, a high level of legal guarantees for banking and commercial secrecy, and loyal government regulation are the features of offshore business. The main advantages of offshore companies are identified in the paper, namely: simple registration; minimum commission; flexible management and minimum reporting requirements, minimum number of directors and shareholders; financial statements, information on accounts and annual income is either completely unnecessary or is minimal; lack of currency control; favorable local corporate legislation, favorable legal framework to encourage and stimulate the offshore industry development; high privacy and so on. One of the global trends of the offshore jurisdiction using by TNCs is considered. It has been found, that the total amount of funds in offshore

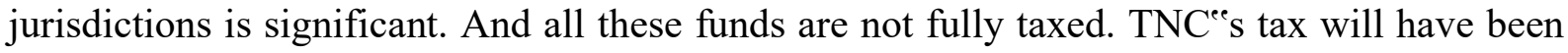
paid if the funds had been brought to the countries where their parent companies are resident. But the opportunity to establish branches in offshore harbors determines, firstly, the economic opportunities to the countries where the TNCs are registered, and secondly, through accelerated capital accumulation, it gives these TNCs not only market, economic, but also a political power, and therefore, they are becoming a major players on the world arena. The world ${ }^{\text {ee }}$ largest financial centers are investigated by index GCFI in 2018. It is concluded, that New York remains in first place by index, just 7 points ahead of London. Hong Kong is in the third place, while Singapore is in the fourth one. Shanghai, Tokyo, Toronto, Zurich, Beijing and Frankfurt remain in the top ten. It is found that, nowadays, the global process of offshoring in economy absorbed almost all countries. According to the OECD datas, the world loses about \$20 trillion annually through offshore, which is $10 \%$ of the country economy. In recent years, the global community has been very concerned about the offshore companies activity. New approaches to combat offshore are developed each year. Therefore, it is fair to say that the world has begun a global process of de-offshore economy.

Key words: offshore, offshore business, offshore jurisdiction, economic security of the country, process of de-offshore economy. 


\section{REFERENCES}

1. Fichtner, Jan. The Offshore-Intensity Ratio. URL: https://www.researchgate.net/ publication/281460648_The_Offshore-Intensity_Ratio.

2. Hendrikse, Reijer, Fernandez, Rodrigo. Offshore Finance. How Capital Rules the World. URL: https://www.researchgate.net/publication/330713868_Offshore_Finance_How_Capital_Rules_ the_World.

3. Alstadsжter, A., Johannesen, N., Zucman, G. (2018). Who owns the wealth in tax havens? Macro evidence and implications for global inequality. Journal of Public Economics, 162 (2018), P. 93. URL: https://www.longfinance.net/media/documents/GFCI_25_Report.pdf.

4. Karlin, M. I., Ivashko, O. A. (2017). Investytsiini ofshory: navch. posib. Lutsk: VezhaDruk, 292 p. URL: http://esnuir.eenu.edu.ua/bitstream/123456789/12272/1/inv_ofshory.pdf.

5. Lutsyshyn, Z., Mekhtiiev, E. (2017). Ofshorni finansovi tsentry u hlobalnomu rusi kapitaliv. Mizhnarodna ekonomichna polityka, № 2, P. 62-94. URL: http://ir.kneu.edu.ua/ handle/2010/23852.

6. Lutsyshyn, Zoriana. (2019). Suchasna ofshoryzatsiia biznesu u konstrukti natsionalnoi fiskalnoi bezpeky/Zoriana Lutsyshyn, Tetiana Frolova, Nina Yuzhanina, Mykola Mazur, Dmytro Perebyinis. Mizhnarodna ekonomichna polityka, Vyp. 1(30), P. 70-112. URL: http://iepjournal.com/journals/ 30/2019_4_Lutsyshyn_\%20Frolova_Yuzhanina_Mazur_Perebyinis.pdf.

7. Martynenko, V. O., Hordiienko, V. P. (2018). Analiz funktsionuvannia ofshornykh zon ta shliakhy podolannia naslidkiv yikh nehatyvnoho vplyvu na ekonomiku Ukrainy. Ekonomika ta suspilstvo, № 10, P. 154-160. URL: http://www.economyandsociety.in.ua/journal/15_ukr/25.pdf.

8. Mosakova, E. A. Offshornbii byznes kak faktor natsyonalnoi bezopasnosty v sovremennom hlobalnom myre. URL: https://cyberleninka.ru/article/n/offshornyy-biznes-kak-faktor-natsionalnoybezopasnosti-v-sovremennom-globalnom-mire.

9. Cherleniak, I. I., Diuhovanets, O. M. (2014). Mizhnarodnyi ofshornyi biznes ta hlobalna finansova systema. Problemy ekonomiky, № 2, P. 24-29. URL: http://nbuv.gov.ua/UJRN/ Pekon_2014_2_3. c. 26/

10. Peshko, A. V. (2016). Ofshornyi biznes yak skladova svitovoi ekonomiky. Ekonomika ta pidpryiemnytstvo, № 3, P. 233-236.

11. Countering offshore tax evasion. URL: https://www.oecd.org/ctp/exchange-of-taxinformation/42469606.pdf

12. Volkova, Yu. A. (2010). Rozvytok ofshornykh tsentriv u systemi mizhnarodnoho biznesu. Formuvannia rynkovykh vidnosyn v Ukraini, № 1, P. 43-48.

13. Kheifets, B. A. (2010). Offshornble yurysdyktsyy v hlobalnoi y natsyonalnoi эkonomyke. Moskva: Ekonomika, 335 p.

14. Ofshor - chto эto takoe prostbim yazblkom? Razbyraemsia v prychynakh skandala. URL: https://sputnik-georgia.ru/amp/spravka/20160406/231003155/Ofshor-chto-jeto-takoeprostymjazykom-Razbiraemsja-v-prichinah-skandala.html.

15. Ofshorni zony: vydy ta osoblyvosti. Hazeta Vikna. URL: http://vikna.if.ua/cikavo/ 68688/view.

16. Mizhnarodne opodatkuvannia: navch. posib. dlia stud. ekonomich. spets./V. I. Hrushko, Yu. O. Makhortov, N. A. Telichko, V. M. Borodachova; Derzh. zakl. «Luhan. nats. un-t imeni Tarasa Shevchenka». Luhansk: Vyd-vo DZ «LNU imeni Tarasa Shevchenka», 2012, 382 p. URL: http://dspace.luguniv.edu.ua/jspui/bitstream/123456789/715/1/Telichko\%20mizn.pdf.

17. Ahapova, A. I., Lobodzynska, T. P. (2018). Naslidky diialnosti ofshornykh kompanii ta shliakhy yikh podolannia. Suchasni problemy ekonomiky i pidpryiemnytstvo, Vyp. 22, P. 126-134.

18. Iaroshevych, V., Sarhan, A. (2013). Offshornыi sehment myrovoi эkonomyky: эvoliutsyia y tendentsyy razvytyia. Bankay̆ski vesnik. Sakavik, P. 33-39. 
19. Offshore Shell Games (2017). The Use of Offshore Tax Havens by Fortune 500 Companies. URL: https://itep.org/wp-content/uploads/offshoreshellgames2017.pdf.

20. Hidden Corners of the Global Economy. URL: https://www.imf.org/external/pubs/ft/ fandd/2019/09/pdf/fd0919.pdf.

21. Foreign direct investment, net inflows (BoP, current US\$). URL: https://data.worldbank. org/indicator/BX.KLT.DINV.CD.WD.

22. Paying Taxes (2018). URL: https://www.pwc.com/gx/en/paying-taxes/pdf/pwc_paying_ taxes_2018_full_report.pdf.

23. The Global Financial Centres Index 22 March (2019). URL: https://www.longfinance. net/media/documents/GFCI_25_Report.pdf.

24. Global Wealth (2019): Reigniting Radical Growth. URL: https://www.bcg.com/ publications/2019/global-wealth-reigniting-radical-growth.aspx.

25. Pidhurska, O. (2016). Tendentsii mizhnarodnoi ta natsionalnoi antyofshornoi polityky. Formuvannia rynkovoi ekonomiky v Ukraini: zb. nauk. pr./Lviv. nats. un-t im. I. Franka; [redkol.: S. M. Panchyshyn ta in.]. Lviv, Vyp. 35, ch. 2, P. $94-99$.

26. Svit proshchaietsia z of shoramy: Ukraina na cherzi. URL: https://www.epravda.com.ua/ projects/offshore/2019/10/21/652665/

27. FATF. What do we do. URL: https://www.fatf-gafi.org/about/whatwedo/\#d.en.3146.

28. High-risk and other monitored jurisdictions. URL: https://www.fatf-gafi.org/ publications/high-risk-and-other-monitored-jurisdictions/documents/fatf-compliance-october2019.html.

29. Tokmenko, V. V. (2014). Suchasnyi stan ta tendentsii hlobalnoho rehuliuvannia ofshornoho biznesu. Nauk. visn. Kherson. derzh. un-tu. Seriia: Ekonomichni nauky. Kherson, Vyp. 8, ch. 6, S. 35-38. URL: http://www.ej.kherson.ua/journal/economic_08/275.pdf.

30. Shokruta, V. Hlobalna deofshoryzatsiia, peredumovy yii vynyknennia. URL: http://yurgazeta.com/publications/practice/inshe/globalna-deofshorizaciya-ta-yiyi-vpliv-na-zed.html.

31. Ukraina i plan BEPS: chomu ofshory vidkhodiat u mynule. URL: https://www.epravda. com.ua/projects/offshore/2019/10/29/652879.

Матеріал надійшов до редакції 10.02.2020 p.

УДК 327:[314.743(477)+659.4]

\section{Марина Пашкевич,}

доктор економічних наук, професор, завідувач кафедри обліку і аудиту,

Національний технічний університет «Дніпровська політехніка»,

pashkevych.m.s@nmu.one

\section{Віктор Пашков,}

кандидат політичних наук, доцент кафедри обліку і аудиту,

Національний технічний університет «Дніпровська політехніка»,

https://orcid.org/0000-0003-4273-2181

viktor.pashkov.polit@gmail.com 